Jurnal Akuntansi \& Manajemen

Vol. 13, No. 1, 2018, Hal:93-111

\title{
Pengaruh Tingkat Pendidikan dan Penggunaan Informasi Akuntansi Manajemen Terhadap Kinerja UMKM di Kota Padang
}

\author{
Rini Frima1, Firman Surya² \\ 1 Jurusan Akuntansi, Politeknik Negeri Padang \\ Email:rinifrima1984@gmail.com \\ ${ }^{2}$ Jurusan Akuntansi, Politeknik Negeri Padang \\ Email:firm4an@gmail.com
}

\begin{abstract}
ABSTRAK
Penelitian ini menganalisa tingkat pendidikan pemilik, penggunaan informasi akuntansi manajemen terhadap kinerja usaha pada Usaha Mikro Kecil Menengah (UMKM) yang ada di Kota Padang. Pendekatan yang digunakan digunakan dalam penelitian ini adalah statistik deskriptif dan pengujian hipotesis menggunakan analisis regresi linear. Sampel yang digunakan dalam penelitian ini adalah UMKM dengan klaster Kecil di Kota Padang. Sampel dalam penelitian ini adalah 25 UMKM yang berada di Kota Padang.

Dari hasil analisa data menggunakan statistik deskriptif atas varibel tingkat pendidikan manajer UMKM menunjukkan bahwa 16\% pendidkan SD/SMP, 36\% berlatar belakang pendidikan SMA/SMK/sederajat, 8\% lulusan D 3 dan 40\% lulusan S1/D4. Sementara untuk variable penggunaan informasi akuntansi manajemen diukur menggunakan 13 indikator. Indikator dengan nilai tertinggi adalah penggunaan buku penjualan dan Buku Kas Masuk. Sementara indikator laporan keuangan yang digunakan untuk mengajukan kredit penggunaanya sangat rendah yaitu sebesar $16 \%$.. Hasil pengujian regresi menggunakan software akuntansi (SPSS 20.0) menunjukkan bahwa tingkat pendidikan tidak berpengaruh terhadap kinerja UMKM, sementara itu penggunaan informasi akuntansi manajemen sangat berpengaruh terhadap kinerja UMKM. Proporsi pengaruh variabel independen terhadap variabel dependen yaitu sebesar 34,8\%. Artinya pendidikan dan Penggunaan Informasi Akuntansi Manajemen memiliki pengaruh terhadap kinerja mencapai 34,8\%.
\end{abstract}

Keyword: Tingkat pendidikan, Informasi Akuntansi Manajemen dan Kinerja.

\section{Pendahuluan}

Indonesia merupakan salah satu Negara berkembang, dimana sebuah negara berkembang sangat focus akan pembangunan dan pertumbuhan ekonomi kearah yang lebih baik. Salah satu yang membangun pertumbuhan ekonomi yaitu Usaha Mikro Kecil dan Menengah (UMKM). UMKM dinilai mampu menciptakan lapangan pekerjaan yang produktif. Usaha Mikro Kecil Menengah (UMKM) adalah kegiatan ekonomi yang dilakukan oleh sebagian besar masyarakat Indonesia sebagai tumpuan dalam memperoleh pendapatan. Data 
Kementerian Koperasi dan Usaha Kecil dan Menengah (2011) menyatakan bahwa presentase UMKM di Indonesia mencapai 99,99\% dan hanya 0,01\%nya adalah usaha besar. Walaupun UMKM bukan merupakan usaha besar, namun peran UMKM dalam menggerakkan sektor perekonomian negara tidak dapat diragukan. Wismiarsi, dkk (2008) menjelaskan bahwa UMKM telah berperan besar dalam menggerakkan pertumbuhan ekonomi di Indonesia.

Peran besar UMKM terhadap sektor perekonomian ini telah mampu menyelamatkan negara dari berbagai krisis ekonomi yang melanda. Salah satunya adalah dalam peristiwa krisis ekonomi eropa yang berdampak terhadap berbagai negara di dunia. Dengan melihat peran besar UMKM serta proporsi unit usaha yang mencapai 99,99\% dari keseluruhan jenis usaha, maka pengembangan UMKM perlu untuk dilakukan. Fokus pengembangan UMKM dapat berupa kualitas produk yang dihasilkan, pengembangan skala usaha, maupun peningkatan jumlahunitusaha.Pengembangan UMKM yang dilakukan dengan baik dapat membantu penyerapan tenaga kerja serta meningkatkan perekonomian negara.

Namun pengembangan UMKM bukanlah sesuatu yang mudah dilakukan dan peran Pemerintah juga ikut serta dalam upaya membantu pengembangan UMKM ke arah yang lebih baik. Upaya pemerintah tersebut masih membutuhkan penangananyang lebih serius. Faktor utama penyebab permasalahan yang dapat mengakibatkan kegagalan pengusaha kecil dan menengah dalam mengembangkan usahanya adalah ketidakmampuan akuntansi dankurangnya informasi dari dalam maupun luar usaha (Astuti,2007).

Informasi akuntansi yang ada dalam laporan keuangan tidak hanya berguna dalam hal pengukuran kinerja usaha namun juga membantu dalam hal permodalan. Laporan keuangan saat ini diperlukan sebagai syarat pengajuan kredit. Namun, kredit yang disalurkan ke UMKM menjadi tersendat akibat adanya kurangnya informasi antara pihak UMKM pada bank pemberi kredit. Laporan keuangan yang diminta oleh bank pemberi kredit menjadi sebuah informasi akuntansi yang berharga bagi kedua belah pihak. Bank membutuhkan laporan keuangan yang lengkap agar dapat mengetahui perkembangan usaha pemohon kredit, sehingga dapat memutuskan permohonan pengajuan kredit. UMKM juga membutuhkan laporan keuangan agar bank dapat memenuhi permohonan kreditnya. Namun hal ini masih belum terlaksanadenganbaikkarena kurangnyakesadaranUMKM terhadap penyediaan laporan keuangan.

Selain menghasilkan informasi berupa laporan keuangan untuk tujuan pengajuan kredit ke Bank, lebih luas sistem informasi akuntansi juga mampu menghasilkan informasi akuntansi manajerial. Data-data keuangan dapat diolah lebih jauh untuk membantu pemilik menjalankan usaha. Sistem informasi akuntansi dapat menghasilkan laporan-laporan yang digunakan oleh pihak internal, seperti laporan harga pokok produksi, laporan profitabilitas segmen/divisi/produk, anggaran dan standar, laporan profitabilitas pelanggan, diferensial reporting dan laporan lainnya. 
Namun, beberapa hasil penelitian menunjukkan bahwa informasi akuntansi masih sangat rendah dimanfaatkan oleh UMKM. Berbagai macam faktor diungkapkan diantaranya: latar belakang pendidikan, skala usaha dan umur perusahaan. Selain itu beberapa penilitian juga mengungkapkan faktor lingkungan bisnis juga mempengaruhi penggunaan informasi akuntansi tersebut. Usaha yang berada pada lingkungan bisnis yang kompetitif lebih membutuhkan informasi akuntansi dibanding lingkungan bisnis yang tingkat persaingannya rendah.

Menurut data Dinas Koperasi dan UMKM Kota Padang tahun 2016 terdapapat 2.062 UMKM di Kota Padang yang beroperasi pada berbagai sektor. Angka tersebut mengalami pertumbuhan dari tahun ke tahun. Lingkungan bisnis yang semakin kompetitif mengharuskan pemilik usaha untuk lebih responsif terhadap perubahan-perubahan yang terjadi. Oleh karena itu, pemilik sangat membutuhkan informasi yang dapat membantu mengambil keputusan bisnis. Berdasarkan latar belakang tersebut, maka rumusan masalah dalam penelitian ini adalah:

1. Bagaimana karakteristik usaha, informasi akuntansi manajemen dan Kinerja UMKM di Kota Padang?

2. Bagaimana pengaruh pendidikan pemilik dan informasi akuntansi manajemen terhadap kinerja usaha pada UMKM di Kota Padang?

\section{Kajian Literatur}

Untuk membedakan jenis usaha mikro, kecil dan menengah, Undang-Undang Republik Indonesia nomor 20 tahun 2008 pasa 16 tentang Usaha Mikro, Kecil dan Menengah mengacu keapada kriteria usaha, yaitu:

1. Usaha Mikro :

a. Usaha produktif milik orang perorangan dan/atau badan usaha perorangan yang memenuhi criteria usaha mikro.

b. Memiliki kekayaan bersih paling banyak Rp50.000.000,00 (lima puluh juta rupiah) tidak termasuk tanah dan bangunan tempat usaha atau memiliki hasil penjualan tahunan paling banyak Rp300.000.000,00 (tigaratus juta rupiah).

2. UsahaKecil :

a. Usaha ekonomi produktif yang berdiri sendiri, yang dilakukan oleh orang perorangan atau badan usaha yang bukan merupakan anak perusahaan atau bukan cabang perusahaan yang dimiliki, dikuasai, atau menjadi bagian baik langsung atau maupun tidak langsung dari usaha menengah atau usaha besar yang memenuhi criteria usaha kecil.

b. Memiliki kekayaan bersih lebih dari Rp50.000.000,00 (limapuluh juta rupiah) sampai dengan paling banyak Rp500.000.000,00 (lima ratus juta rupiah) bangunan tempat usaha atau memiliki hasil penjualan tahunan lebih dari Rp300.000.000,00 (tiga ratus juta rupiah) sampai dengan paling banyak Rp2.500.000.000,00 (dua milyar lima ratus juta rupiah).

3. UsahaMenengah : 
a. Usaha ekonomi produktif yang berdiri sendiri, yang dilakukan oleh orang perorangan atau badan usaha yang bukan merupakananak perusahaan atau bukan cabang perusahaan yang dimiliki, dikuasai, atau menjadi bagian baik langsung atau maupun tidak langsung dengan usahakecil atau usaha besar.

b. Memiliki kekayaan bersih lebih dari Rp500.000.000,00 (limaratus jutarupiah) sampai dengan paling banyak Rp10.000.000.000,00 (sepuluh milyar rupiah) tidak termasuk tanah dan bangunan tempat usaha atau memiliki hasil penjualan tahunan lebih dari Rp2.500.000.000,00 (dua milyar lima ratus juta rupiah) sampai dengan paling banyak Rp50.000.000.000,00 (lima puluh milyar rupiah).

Menurut Harimurti (2001), pada hakekatnya usaha kecil yang ada secara umum dikelompokkan ke dalam 3 (tiga) golongan yaitu:

a. Industri kecil: industry kerajinan rakyat, industry cor logam, konveksi dan berbagai industri lainnya.

b. Perusahaan berskala kecil: penyalur, toko kerajinan, koperasi, waserba, restoran, toko bunga, jasa profesi dan lainnya.

c. Sektor informal: agen barang bekas, kios kaki limadan lainnya.

Menurut Kellen(2004), secara umum usaha kecil dan menengah memiliki karakteristik antara lain :

1. Sistem pembukuan sederhana

2. Margin usahayangtipis karenapersainganyangsangat tinggi

3. Modal terbatas

4. Pengalaan manajerialyangterbatas

Selain itu usaha kecil dan menengah juga tergolong dalam usaha rumahan. Sehingga cenderung memiliki waktu usaha yang singkat.

Administrasi pembukuan yang sistematis dengan sistem akuntansi merupakan suatu kegiatan yang harus dan sebaiknya dilakukan oleh suatu usaha bisnis, guna menilai konsisi dan potensi usaha. Pola pengelolaan keuangan dan sistem akuntansi yang diterapkan pada usaha kecil dapat berpedoman kepada pola umum yang telah dikenal dan digunakan oleh berbagai perusahaan besar, namun jika kurang sesuai dapat dimodifikasi sesuai dengan keperluan dengan tetap memperhatikan fungsi perencanaan dan pengawasan. Administrasi pembukuan usaha kecil memerlukan minimal 3 jenis buku pencatatan meliputi: Buku harian, Buku jurnal, Buku besar, (Harimurti Subanar, 2001).

\section{Permasalahan dalam Usaha Mikro,Kecil dan Menengah (UMKM)}

Usaha Mikro, Kecil dan Menengah mempunyai beberapa permasalahan, menurut Tambunan (2009),yaitu sebagai berikut:

1. Faktor Internal

b. Kurangnya permodalan

Permodalan merupakan faktor utama yang diperlukan untuk mengembangkan suatu unit usaha. Kurangnya permodalan UMKM, 
karena pada umumnya usaha Mikro, Kecil dan Menengah merupakan usaha perorangan atau perusahaan yang sifatnya tertutup.

c. Sumber Daya Manusia yang Terbatas

Keterbatasan SDM usahaMikro, Kecil dan Menengah baik dari segi pendidikan formal maupun pengetahuan dan keterampilannya sangat berpengaruh pada manajemen pengelolaan usahnya, sehingga usaha tersebut sulit untuk berkembang secaraoptimal.

d. Lemahnya Jaringan Usaha dan Kemampuan Penentrasi Usaha Kecil Jaringan usaha yang sangat terbatas dan kemampuan penetrasi rendah maka produk yang dihasilkan jumlahnya sangat terbatas dan mempunyai kualitas yang kurang kompetitif.

2. Faktor Eksternal

a. Iklim usaha belum sepenuhnya kondusif dengan kebijaksanaan pemerintah untuk menumbuhkembangkan Usaha Mikro,Kecildan Menengah (UMKM). Terlihat dari masih terjadinya persaingan yang kurang sehat antara pengusaha-pengusahak ecil dan menengah.

b. Terbatasnya Sarana dan Prasarana Usaha

Kurangnya informasi yang berhubungan dengan kemajuan ilmu pengetahuan dan teknologi menyebabkan sarana dan prasarana yang mereka miliki juga tidak cepat berkembang dan kurang mendukung kemajuan usaha.

\section{Informasi Akuntansi}

Fitriyah (2006) menyatakan bahwa informasi akuntansi pada dasarnya bersifat keuangan dan terutama digunakan untuk tujuan pengambilan keputusan, pengawasan,dan implementasi keputusan-keputusan perusahaan. Agar data keuangan dapat dimanfaatkan denganbaik oleh pihak internal maupun eksternal perusahaan,maka data tersebut harus disusun dalam bentuk-bentuk yang sesuai.

Menurut Mulyadi (2009) akuntansi secara garis besar dapat dibagi menjadi dua tipe yaitu:

1. Akuntansi Keuangan

Akuntansi keuangan terutama ditujukan untuk menyajikan informasi bagi pemakai luar perusahaan. Untuk suatu perusahaan yang besar, pemakai luar ini meliputi pemegang saham, kreditur, langganan, para analis keuangan, karyawan, dan berbagai instansi pemerintah. Akuntansi keuangan menghasilkan laporan keuangan periodic yang umumnya terdiri dari neraca, laporan rugi-laba, laporan perubahan laba, dan laporan perubahan posisi keuangan. Informasi akuntansi yang disajikan untuk pihak luar perusahaan ini memerlukan ketepatan yang tinggi karena umumnya menyangkut masa yang telah lalu.

2. AkuntansiManajemen

Akuntansi manajemen ditujukan untuk menyediakan informasi keuangan bagi keperluan manajemen. Akuntansi manajemen berhubungan 
dengan informasi mengenai perusahaan untuk memberikan manfaat bagi mereka yang ada dalam perusahaan. Akuntansi manajemen ini menghasilkan laporan keuangan rinci dari berbagai jenjang organisasi yang menyajikan informasi rinci. Informasi akuntansi yang dihasilkan oleh akuntansi manajemen digunakan untuk pengambilan keputusan oleh para manajer.

\section{Penggunaan Informasi Akuntansi dalam Perusahaan}

Dalam Solovida (2010) menjelaskan bahwa kekurangan informasi akuntansi dalam manajemen perusahaan dapat membahayakan perusahaan kecil. Selanjutnya mereka menyatakan bahwa kondisi keuangan yang memburuk dan kekurangan catatan akuntansi akan membatasi akses untuk memperoleh informasi yang diperlukan, sehingga akan menyebabkan kegagalan perusahaan.

Faktor-faktor yang mempengaruhi penggunaan informasi akuntansi pada usaha kecil dan menengah dalam Fitriyah (2006) ada empat faktor, yaitu:

1. Pengetahuan akuntansi

Pengetahuan akuntansi sangat diperlukan oleh manajer atau pemilik perusahaan dalam menjalakan operasional perusahaan. Jika pengetahuan manajer atau pemilik rendah, akan menyebabkan banyak perusahaan kecil dan menengah menggunakan jasa Konsultan atau Akuntan Publik dalam penyediaan informasi akuntansi.

2.

kalausaha

Skala usaha merupakan kemampuan perusahaan dalam mengelola usahanya dengan melihat berapa jumlah karyawan yang bekerja dan berapa besar pendapatan yang diperoleh perusahaan dalam satu periode akuntansi.

3.

enisusaha

Jenis usaha mempunyai efek terhadap persiapan dan penggunaan informasi akuntansi.

4.

engalaman usaha

Pengalaman dalam operasional berusaha atau lamanya perusahaan beroperasi berdasarkan pada bisnis yang sudah dijalankan akan mengindikasikan kebutuhanakan informasi akuntansiyang sangat diperlukan dalam.

Aspek-aspek Penggunaan Informasi Akuntansi antara lain:

1.

endidikan Pemilik atau Manajer Perusahaan

Menurut Astuti (2007), pemilik atau manajer perusahaan kecil dan menengah sangatlah dominan dalam menjalankan usaha dalam 
perusahaan. Kemampuan dan keahlian pemilik atau manajer perusahaan sangat mempengaruhi penggunaan informasi akuntansi. Kemampuan dan keahlian pemilik atau manajer perusahaan kecil dan menengah ditentukan dari tingkatan pendidikan formal yang pernah ditempuh. Tingkat pendidikan formal ini mempengaruhi penggunaan informasi akuntansi. Tingkatan pendidikan formal yang rendah (tingkatan pendidikan sekolah dasar sampai dengan sekolah menengah umum) pemilik atau manajer, akan mengakibatkan penggunaan informasi akuntansi yang lebih rendah jika dibandingkan dengan tingkatan pendidikan formal yang tinggi (perguruantinggi) pemilik atau manajer. Ini disebabkan materi pengajaran akuntansi yang lebih lanjut diberikan 2. diperguruan tinggi (Astuti,2007).

elatihanAkuntansi

Jain (2009) dalam Astuti (2007) menyatakan bahwa pelatihan akan menghasilkan peningkatan professional yang jauh lebih baik dalam manajemen. Penelitian Holmes dan Nicholls (1988, 1989) dalam Astuti (2007) menunjukkan bahwa pelatihan berhubungan positif terhadap penyediaan informasi akuntansi untuk membuat keputusan dalam perusahaan kecil. Manajemen yang dipakai dalam kursus pelatihan cenderung menghasilkan lebih banyak informasi akuntansi statutori, anggaran, dan tambahan dibandingkan dengan mereka yang kurang pelatihan.

\section{Kinerja}

Perusahaan sebagai salah satu bentuk organisasi pada umumnya memiliki tujuan tertentu yang ingin dicapai dalam usaha untuk memenuhi kepentingan para anggotanya. Keberhasilan dalam mencapai tujuan perusahaan merupakan prestasi manajemen. Penilaian prestasi atau kinerja suatu perusahaan diukur karena dapat dipakai sebagai dasar pengambilan keputusan baik pihak internal maupun eksternal.

Pengertian kinerja menurut Kaplan dan Norton (1996) yaitu:

"The objective of any measurement system should to be motivate all managers and emplotees to implement succesfully the bussiness unit's strategy."

Menururt Ikatan Akuntan Indonesia (2002), kinerja perusahaan dapat diukur dengan menganalisa dan mengevaluasi laporan keuangan. Informasi posisi keuangan dan kinerja keuangan di masa lalu seringkali digunakan sebagai dasar untuk memprediksi posisi keuangan dan kinerja di masa depan.

Kinerja perusahaan merupakan sesuatu yang dihasilkan oleh suatuperusahaan dalam periode tertentu dengan mengacu pada standar yang ditetapkan.Kinerja perusahaan hendaknya merupakan hasil yang dapat diukurdan menggambarkan kondisi empirik suatu perusahaan dari berbagai ukuran yang disepakati (Yurniwati, 2003). 
Kinerja merupakan hal penting yang harus dicapai oleh setiap perusahaan, karena kinerja mencerminkan kemampuan perusahaan dalam mengelola dan mengalokasikan sumberdayanya. Kinerja perusahaan diukur dengan menggunakan pengukuran subyektif yang mendasarkan pada persepsi staf dan manajer perusahaan atas berbagai dimensi pengukuran kinerja perusahaan. Dimensi pengukuran kinerja yang lazim digunakan dalam berbagai penelitian adalah pertumbuhan (growth), kemampulabaan (profitability) dan efisiensi (Murphy,et.al, 1996) dalam Yurniwati (2003).

Penilaian kinerja perusahaan dapat diukur dengan ukuran keuangan dan non keuangan. Ukuran keuangan untuk mengetahui hasil tindakan yang telah dilakukan dimasa lalu dan ukuran keuangan tersebut dilengkapi dengan ukuran non keuangan tentang kepuasan customer, produktivitas dan cost effectiveness proses bisnis/intern serta produktivitas dan komitmen personel yang akan menentukan kinerja keuangan masa yang akan datang. (Yurniwati, 2003).

Sehingga dapat dikatakan bahwa kinerja perusahaan menrupakan suatu capaian perusahaan yang dapat diukur dengan suatu kriteria tertentu. Kriteria yang dipakai untuk mengukur suatu capaian dapat berupa nilai keuangan dan non keuangan. Melalui data dan informasi capaian tersebut, diharapkan dapat mendatangkan kesejahteraan bagi pihak yang berkepentingan dengan perusahaan.

\section{Hasil dan Pembahasan}

Data pada penelitian ini diperoleh dengan menyebarkan kuesioner kepada responden yang terdaftar di Dinas Koperasi dan UMKM Kota Padang pada tahun 2016 yaitu 2040 UMKM. Penyebaran kuesioner dilakukan dengan mendatangi secara langsung UMKM yang menjadi lokasi pengambilan sampel dan membagikannya kepada responden. Proses penyebaran hingga pengumpulan data dilakukan kurang lebih selama 5 minggu yaitu dari tanggal 26 Mei hingga 3 Juli 2018.

Kuesioner yang dibagikan kepada responden adalah UMKM yang tergolong kecil dan menengah. Menurut data Dinas Koperasi dan UMKM Kota Padang tahun 2016, jumlah UMKM yang tergolong kecil dan menengah yang ada di kota Padang

Berikut ini adalah rincian total kuisioner yang dapat diolah:

Tabel 1

\section{Deskripsi Kuisioner Penelitian}

\begin{tabular}{lc}
\multicolumn{1}{c}{ Keterangan } & Jumlah \\
\hline Kuesioner yang disebar & 35 \\
Kuesioner yang kembali & 25 \\
Kuesioner yang tidak kembali & 5 \\
Kuesioner yang kembali tetapi tidak dapat & -
\end{tabular}




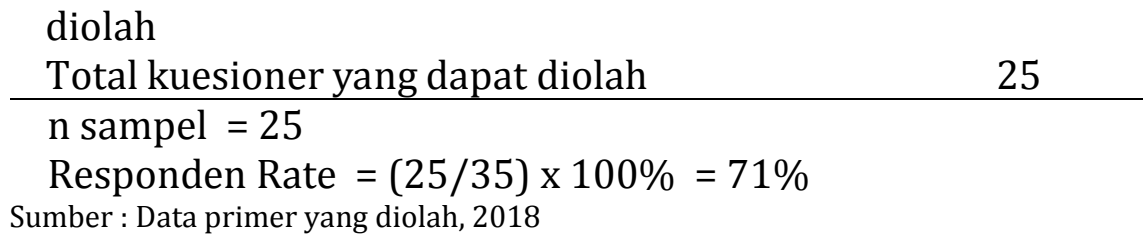

Dari 35 kuesioner yang disebar, sebanyak 5 buah kuesioner tidak kembali. Kuesioner yang kembali dan diolah sebanyak 25 buah dengan responden rate sebesar $71 \%$.

\section{Karakteristik Responden}

Dari hasil pengumpulan data menggunakan kuesioner maka diperoleh karakteristik responden sebagai berikut:

Tabel 2

\begin{tabular}{lll}
\multicolumn{2}{c}{ Karakteristik Responden Berdasarkan } & \multicolumn{2}{c}{$\begin{array}{l}\text { Jenis Kelamin } \\
\text { Jenis Kelamin }\end{array}$} & Jumlah & Persentase (\%) \\
\hline Laki-laki & 16 & 64 \\
Perempuan & 9 & 36 \\
\hline Total & $\mathbf{2 5}$ & $\mathbf{1 0 0 \%}$
\end{tabular}

Sumber : Data Primer diolah, 2018

Sebesar 64\% responden berjenis kelamin Laki-laki, sisanya sebesar 36\% berjenis kelamin perempuan.

\section{Tabel 3}

\begin{tabular}{|c|c|c|}
\hline \multicolumn{3}{|c|}{ Karakteristik Responden Berdasarkan Usia } \\
\hline Pendidikan & Jumlah & Persentase (\%) \\
\hline$<20$ tahun & 0 & 0 \\
\hline $21-30$ tahun & 5 & 20 \\
\hline $31-40$ tahun & 9 & 36 \\
\hline $41-50$ tahun & 8 & 32 \\
\hline$>50$ tahun & 3 & 12 \\
\hline Total & 25 & $100 \%$ \\
\hline
\end{tabular}

Sumber : Data Primer diolah, 2018

Dari hasil pengumpulan data melaui kuesioner diperoleh data bahwa tidak ada pemilik UMKM yang usianya di bawah 20 tahun. Pemiliki UMKM paling banyak tersebesar pada range usia 31-40 tahun. Diikuti usia 41-50 tahun sebanyak $32 \%$.

\section{Tabel 4}

\begin{tabular}{|c|c|c|}
\hline \multicolumn{3}{|c|}{ Karakteristik Responden Berdasarkan Lama Usaha } \\
\hline Pendidikan & Jumlah & Persentase (\%) \\
\hline$<5$ tahun & 9 & 36 \\
\hline $5-10$ tahun & 10 & 40 \\
\hline $10-15$ tahun & 2 & 8 \\
\hline$>15$ tahun & 4 & 16 \\
\hline Total & 25 & $100 \%$ \\
\hline
\end{tabular}


Sumber : Data Primerdiolah, 2018

Berdasarkan lama usaha atau lama berdirinya UMKM paling banyak adalah yang usianya antara 5-10 tahun yaitu sebanyak 10 responden atau sebbesar $40 \%$.

Tabel 5

\begin{tabular}{lll}
$\begin{array}{c}\text { Karakteristik Responden } \\
\text { Pendidikan }\end{array}$ & Jumlah & $\begin{array}{c}\text { Juah } \\
\text { Persentase (\%) }\end{array}$ \\
\hline $1-5$ orang & 15 & 60 \\
$5-10$ orang & 8 & 32 \\
$>10$ orang & 2 & 8 \\
Total & $\mathbf{2 5}$ & $\mathbf{1 0 0 \%}$
\end{tabular}

Sumber : Data Primer diolah, 2018

Sementara itu, dilihat dari jumlah tenaga kerja yang ada 60\% UMKM memiliki tenaga kerja 1-5 orang. Dan hanya 2 UMKM yang memiliki tenaga kerja diatas 10 Orang.

\section{Tabel 6}

\begin{tabular}{|c|c|c|}
\hline \multicolumn{3}{|c|}{ Karakteristik Responden Berdasarkan Aset } \\
\hline Pendidikan & Jumlah & Persentase (\%) \\
\hline$<50$ Juta & 14 & 56 \\
\hline $50-150$ Juta & 3 & 12 \\
\hline > 150 Juta & 8 & 32 \\
\hline Total & 25 & $100 \%$ \\
\hline
\end{tabular}

Sumber : Data primer diolah, 2018

Berdasarkan range asset yang dimiliki oleh responden UMKM di Kota Padang masih didominasi oleh UMKM skala kecil dengan asset kurang dari 50 Juta.

Tabel 7

$\begin{array}{lll}\begin{array}{c}\text { Karakteristik Responden } \\ \text { Pendidikan }\end{array} & \text { Berdasarkan } & \text { Tingkat Pendidikan } \\ \text { Lainnya (SD/SMP) } & 4 & \text { Persentase (\%) } \\ \text { SMA/SMK } & 9 & 16 \% \\ \text { D3 } & 2 & 36 \% \\ \text { D4/S1 } & 10 & 8 \% \\ \text { Total } & \mathbf{2 5} & 40,0 \% \\ \text { Sulah } & \mathbf{1 0 0 \%}\end{array}$

Sumber : Hasil penelitian yang diolah, 2018

Berdasarkan tabel di atas maka dari 25 responden yang dikumpulkan menunjukkan bahwa tingkat pendidikan Lainnya (SD/SMP), sebanyak 4 orang atau $16 \%$, kemudian responden dengan tingkat pendidikan SMA/SMK sebanyak 9 orang atau 36\%, tingkat pendidikan D3 sebanyak 2 orang atau 8\%, dan sisanya dengan tingkat pendidikan D4/S1 sebanyak 10 orang atau $40 \%$.

\section{Analisis Deskriptif Penggunaan Informasi Akuntansi Manajemen Pada UMKM di Kota Padang}


Analisis indeks jawaban dilakukan untuk memperoleh gambaran deskriptif penelitian yang dilakukan terhadap tiap indikator dari variabel penggunaan informasi akuntansi manajemen yang digunakan untuk mengetahui respon responden terhadap setiap pernyataan yang diajukan. Dalam penelitian ini, kuesioner yang dibagikan menggunakan skala Guttman. Setiap item pertanyaan di dalam kuesioner diberi pilihan jawaban Ya atau Tidak. Sebanyak 13 pernyataan mengenai penggunaan informasi akuntansi manajemen diberikan kepada responden. Setiap item jawaban diberikan nilai sebagai berikut:

$$
\begin{array}{ll}
\text { Ya } & =1 \\
\text { Tidak } & =0
\end{array}
$$

Distribusi dari masing-masing kategori tanggapan responden untuk variabel penggunaan informasi akuntansi manajemen adalah sebagai berikut :

Tabel 8

\section{Penggunaan Informasi Akuntansi Manajemen}

\begin{tabular}{llcc} 
No. & Jenis Informasi Akuntansi & Skor & $\begin{array}{c}\text { Persentase } \\
\text { (\%) }\end{array}$ \\
\hline 1 & Buku Penjualan & 19 & 76 \\
2 & Buku Kas Masuk & 17 & 68 \\
3 & Buku Kas Keluar & 15 & 60 \\
4 & Catatan Absensi Karyawan & 13 & 52 \\
5 & Laporan Stok Barang/Bahan baku & 13 & 52 \\
6 & Laporan Harga Pokok dan Biaya & 12 & 48 \\
7 & Laporan Gaji Karyawan & 12 & 48 \\
8 & Buku Piutang & 11 & 44 \\
9 & Buku Hutang & 10 & 40 \\
10 & Buku Inventaris Kantor/Aset & 7 & 28 \\
11 & Buku Persedian Barang & 7 & 28 \\
12 & Anggaran Penjualan & 6 & 24 \\
13 & Laporan Keuangan & 4 & 16 \\
\hline Data primer diolah 2018 & &
\end{tabular}

Sebanyak 13 jenis informasi akuntansi manajemen yang ditanyakan kepada responden diperoleh hasil seperti tabel 5.8 diatas. Jenis informasi akuntansi manajemen yang paling luas penggunaannya oleh pelaku UMKM adalah Buku Penjulan dan Buku Kas Masuk, sebesar 76\% dan 68\% responden menggunakan informasi ini dalam menjalankan usahanya. Sementara itu informasi akuntansi manajemen yang paling rendah penggunaannya pada UMKM di Kota Padang adalah Anggaran dan Laporan Keuangan dengan persentase 24\% dan 16\%.

\section{Analisis Deskriptif Kinerja UMKM di Kota Padang}

Kinerja UMKM di Kota Padang diukur dengan tiga indikator yaitu: Aset, Pendapatan, dan Kinerja Manajerial. Kinerja asset diukur dengan kepemilikan 
terhadap asset yang terpisah dari kepemilikan pribadi. Sementara itu pendapatan dilihat dari luasnya pendapatan yang berasal dari jenis penjualan tunai dan kredit, serta dilihat dari kepastian dalam memperoleh pendapatan. Untuk kinerja manajerial penilaian dilakukan terhadap kemampuan manajer dalam mengelola bisnis dan melakukan evaluasi. Setiap item pertanyaan yang ada dalam kuesioner diberikan pilihan jawaban "Ya dan tidak". Dimana, Skor 1 untuk jawaban "Ya" dan Skor 0 untuk pilihan jawaban "Tidak"

\section{Tabel 5.9}

\section{Kinerja UMKM}

No. Indikator

1 Aset

2 Pendapatan

3 Kinerja Manajerial

Data primer diolah 2018
Skor

1,44

0,44

5,5
Skala

4

4

7

Dari hasil statistic deskriptif pada tabel 5.9 diatas, terlihat bahwa skor asset dan pendapatan sangat rendah dari nilai maksimal 4. Sementara itu skor indicator kinerja manajerial menunjukkan angka 5,5 dari maksimal skor 7.

\section{Uji Normalitas}

Uji normalitas bertujuan untuk mengetahui apakah dalam model regresi, variabel terikat dan variabel bebas memiliki distribusi yang normal atau mendekati normal. Berikut ini uji normalitas akan disajikan dalam bentuk p-plot tabel. 


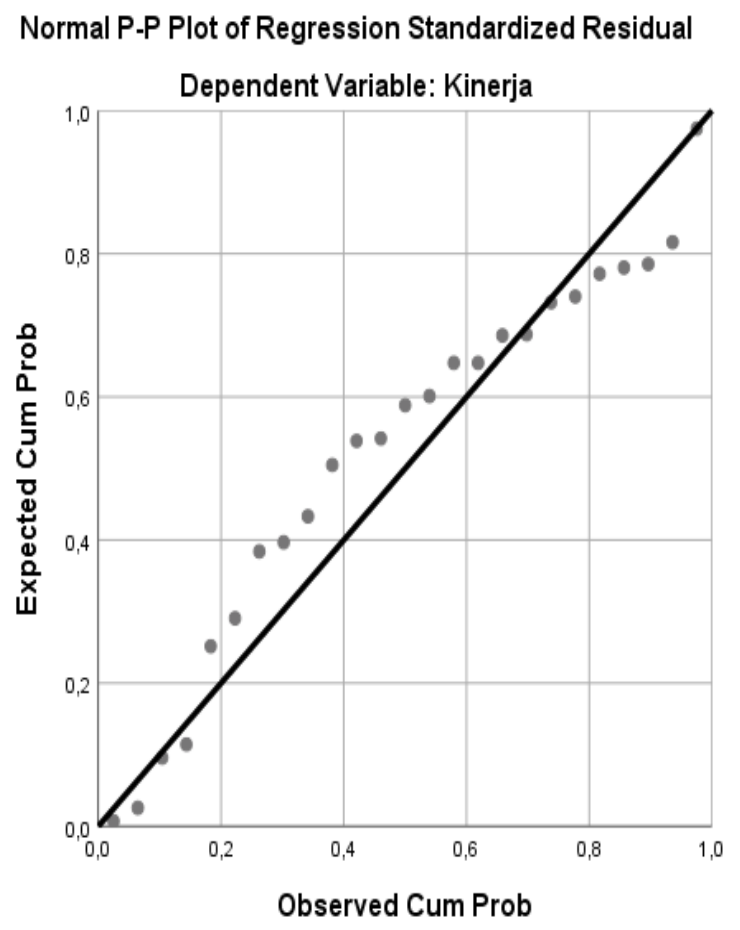

Gambar 1

Dari gambar diatas dapat diketahui bahwa tampilan p-plot terlihat memenuhi asumsi uji normalitas. P-Plot tabel menunjukkan pola mrngikuti grasi linear. Hal ini menunjukkan bahwa model regresi memenuhi asumsi normalitas.

\section{Uji Heteroskedastisitas}

Pengujian heteroskedastisitas dilakukan dengan menggunakan scatterplot. Jika tidak terdapat pola yang teratur pada titik-titik residualnya, maka dapat disimpulkan tidak adanya masalah heteroskedastisitas. Berikut ini adalah gambar hasil pengujian heteroskedastisitas 


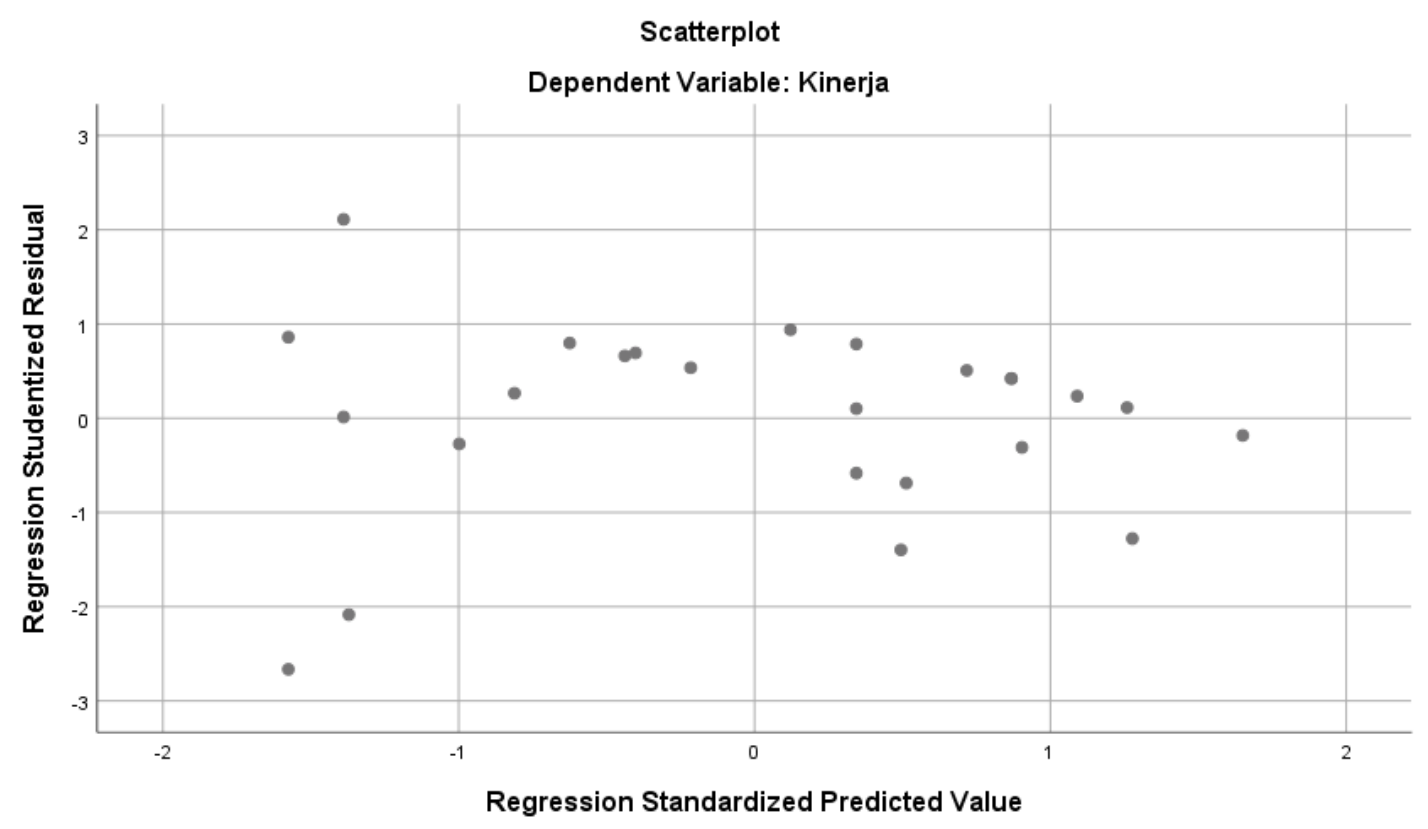

Gambar 2

Scatterplot

Hasil pengujian menunjukkan adanya pola yang tidak teratur serta titik-titik menyebar diatas dan dibawah angka nol pada sumbu Y, maka dapat disimpulkan bahwa tidak terjadi heteroskedastisitas

\section{Uji Hipotesis dan Regresi Linear}

Untuk menguji hipotesis dalam penelitian ini dilakukan menggunakan uji t, dengan melihat tingkat signifikansi t.

Tabel 10

\section{Hasil Uji t dan Analisa Regresi} Coefficients ${ }^{a}$

\begin{tabular}{|c|c|c|c|c|c|c|}
\hline \multirow[b]{2}{*}{ Mode } & & \multicolumn{2}{|c|}{ Unstandardized Coefficients } & \multirow{2}{*}{$\begin{array}{c}\text { Standardized } \\
\text { Coefficients } \\
\text { Beta } \\
\end{array}$} & \multirow[b]{2}{*}{$\mathrm{t}$} & \multirow[b]{2}{*}{ Sig. } \\
\hline & & B & Std. Error & & & \\
\hline \multirow[t]{3}{*}{1} & (Constant) & 3,157 & ,825 & & 3,825 & ,001 \\
\hline & Pendidikan & 422 & 284 & 271 & 1,487 & 151 \\
\hline & Piam & 201 & 083 & ,443 & 2,435 & 023 \\
\hline
\end{tabular}

a. Dependent Variable: Kinerja

Hasil uji menujukkan nilai t hitung pemgaruh pendidikan terhadap kinerja usaha sebesar 1,487 dengan sig 0,151 artinya tingkat pendidikan pemilik UMKM tidak berpengaruh terhadap kinerja usaha. Sementara itu penggunaan informasi akuntansi manajemen memiliki t hitung 2,435 dengan sig 0,023. Artinya penggunaan informasi akuntansi manajemen berpengaruh terhadap kinerja UMKM. Persamaan regresi pengaruh tingkata pendidikan pemilik dan penggunaan informasi akuntnasi manajemen terhadap kinerja usaha adalah $\mathrm{Y}=3,157+0,422$. Pendidikan + 0,201.Piam + e 
Sementara itu variabel tingkat pendidikan dan penggunaan informasi akuntansi manajemen dapat menjelaskan fenomena kinerja UMKM sebesar $34,8 \%$ sementara sisanya dapat dipengaruhi oleh faktor kontekstual lain. Baik yang berasal dari dalam maupun dari luar organisasi.

\begin{tabular}{|c|c|c|c|c|c|}
\hline \multirow[b]{2}{*}{ Model } & \multicolumn{5}{|c|}{$\begin{array}{c}\text { Tabel 11 } \\
\text { Hasil Uji Determinasi } \\
\text { Model Summaryb }\end{array}$} \\
\hline & $\mathrm{R}$ & R Square & $\begin{array}{l}\text { Adjusted R } \\
\text { Square }\end{array}$ & $\begin{array}{l}\text { Std. Error of the } \\
\text { Estimate }\end{array}$ & Durbin-Watson \\
\hline 1 &, $590^{\mathrm{a}}$ & ,348 & ,289 & 1,542 & 1,836 \\
\hline
\end{tabular}

dari hasil penelitian yang ditunujkkan oleh uji t diatas dapat dianalisa bahwa secara langsung pengaruh tingkat pendidikan tidak mempengaruhi kinerja UMKM di Kota Padang. Hal ini dapat dikatakan bahwa ada pengukuran lain yang lebih valid untuk dapat menjelaskan fenomena tersebut. Variabel tersebut dapat saja adalah pengalam manajer dalam menjalankan usaha. Tidak dapat dipungkiri bahwa tingkat pendidikan belum menjamin seorang manajer mampu menjalankan usaha dengan baik. Namun, pengalaman yang membentuk insting usaha seorang manajer. Sementara itu, penggunaan informasi akuntansi ternyata dapat mempengaruhi kinerja UMKM di Kota Padang, artinya ketika manajer diabntu dengan catatan-catatan keuangan perusahaan akan mempengaruhi cara manajer mengambil keputusan. Keputusan yang diambil sudah didasarkan pada informasi yang tersedia. Sehingga risiko bisnis yang dihadapi oleh UMKM dapat dikurangi.

\section{Kesimpulan}

Dari hasil analisa data dan pembahasan mengenai karakterisitik usaha, penggunaan informasi akuntansi manajemen dan kinerja usahaa diperoleh hasil sebagai berikut:

1. Pendidikan pemiliki UMKM paling bayanyak adlah S1/D4 sebesar $40 \%$, dan SMA/SMK/Sederajata sebanyak 36\% dari total responden dalam penelitian ini.

2. Proporsi pengaruh variabel independen terhadap variabel dependen yaitu sebesar 34,8\%. Artinya pendidikan dan Penggunaan Informasi Akuntansi Manajemen memiliki pengaruh terhadap kinerja mencapai $28,9 \%$.

3. Pendidikan tidak berpengaruh terhadap kinerja, karena nilai signifikansi lebih besar dari 0,05 yaitu sebesar 0,151

4. Piam berpengaruh positif terhadap kinerja, karena nilai signifikansi lebih kecil dari 0,05 yaitu sebesar 0,023 dan memiliki arah koefisien positif. 
Penelitian ini memiliki banyak keterbatasa sehingga disarankan hal-hal sebagai berikut:

1. Memperluas lingkup penelitian baik dari jumalah responden, jenis usaha maupun lokasi usaha.

2. Faktor kontektual yang digunakan sebaiknya juga dipertimbangakan yang berasal darai luar usaha.

3. Menggunakan model pengembangan hipotesisi lain.

\section{REFERENSI}

[1] Ardiana, dkk. 2010. Kompetensi SDM UKM dan Pengaruhnya Terhadap Kinerja UKM di Surabaya. Jurnal Manajemen Dan Kewirausahaan, Vol.12, No. 1, Maret 2010: 42-55

[2] Astuti, Era. 2007. Pengaruh Karakteristik Internal Perusahaan Terhadap Penyiapan dan Penggunaaan Informasi Akuntansi Perusahaan Kecil danMenengah di Kabupaten Kudus. Tesis. Semarang: Universitas Diponegoro.

[3] Diah, Linear Sitoresmi. 2013. Faktor-Faktor yang Mempengaruhi Penggunaan Informasi Akuntansi Pada Usaha Kecil dan Menengah (Studi Pada Kub Sido Rukun Semarang).

[4] Ediraras, Dharma T. 2010. Akuntansi dan Kinerja UKM. Jurnal ekonomi dan bisnis.

[5] Ferdinand, Augusty. 2006. Metode Penelitian Manajemen : Pedoman Penelitian untuk Penulisan Skripsi, Tesis, dan Disertasi Ilmu Manajemen. Semarang: Badan Penerbit Universitas Diponegoro.

[6] Fitriyah, Hadiyah. 2006. Analisis Faktor-Faktor yang Mempengaruhi Penggunaan Informasi Akuntansi Pada Usaha Menengah Kabupaten Sidoharjo. Tesis. Surabaya: Universitas Airlangga.

[7] Ghozali, Imam. 2001. Aplikasi Analisis Multivariate Dengan Program SPSS. Semarang: Universitas Diponegoro.

[8] Hadi, Misbakhul. 2016. Analisis Faktor-faktor yang Mempengaruhi Penggunaan Informasi Akuntansi pada UMKM di Kabupaten Sragen. Skripsi. Surakarta: Universitas Muhammadiyah Surakarta.

[9] Harimurti. 2011. Management Usaha Kecil. Yogyakarta: BPFE. 
[10] Hariyadi. 2013. Faktor-Faktor yang Mempengaruhi Penggunaan Informasi Akuntansi Pada Usaha Mikro, Kecil dan Menengah (UMKM) Yang Bergerak Di Bidang Jenis Usaha Makanan Di Kota Tanjungpinang. Skripsi. Tanjung Pinang: Universitas Maritim Raja Ali Haji.

[11] Handiani, Eka. 2011. "Pengaruh Faktor Internal, Eksternal, Entrepreneurship, Strategi dan Kinerja terhadap Daya Saing Usaha Kecil dan Menengah". Jurnal Dinamika Manajemen vol.3 No.1.

[12] Helen, dkk. 2016. Hubungan Sistem Informasi Akuntansi dengan Kinerja Usaha Kecil dan Menengah Di Malaysia. Jurnal Akuntansi, Vol. 4, No. 2, April 2016 : 216-227. ISSN 2337-4314.

[13] Hongren, Charles T. \& Gary L. Sundem. 1993. Management Accounting: Introduction to Management Accounting. $9^{\text {th }}$ edition. Prentice-Hall, Inc. Englewood Cliffs, New Jersey.

[14] Indriantoro, dkk. 1999. Metodologi Penelitian Bisnis Untuk Akuntansi \& Manajemen. Yogyakarta: Penerbit BPFE.

[15] Jumingan dan Rosita. 2012. Analisis Manfaat Informasi Akuntansi Pada Ukm di Wilayah Kabupaten Sukoharjo. GRADUASI Vol. 28 Edisi November 2012. ISSN 2088 - 6594.

[16] Kellen, Pius Bumi. 2004. Peranan Akuntansi Untuk Pengembangan Bisnis Kecil. Jurnal Bisnis dan Usahawan, II No.7

[17] Kementrian Koperasi dan UMKM. 2016.

[18] Kusumadini, Rosilina. 2016. Analisis Faktor-faktor yang Mempengaruhi Penggunaan Informasi Akuntansi pada Usaha Kecil dan Menengah (Studi Kasus pada Usaha Kecil dan Menengah Bidang Furniture di Jawa Tengah). Skripsi. Semarang: Fakultas Ekonomi UNDIP.

[19] Mardalis. 2008. Metode Penelitian Suatu Pendekatan Proposal. Jakarta: PT Bumi Aksara.

[20] Mahsun, Muhammad. 2006. Pengukuran Kinerja Sektor Publik. Yogyakarta: BPFE.

[21] Meilani. 2015. Analisis Faktor - Faktor yang Mempengaruhi Persepsi Penerapan Akuntansi pada Para Pemilik UKM (Usaha Kecil dan Menengah) 
Toko Bangunan di Daerah Cengkareng, Jakarta Barat. Skripsi. Universitas Esa Unggul.

[22] Priyatno, Duwi. 2016. SPSS hand book analisis data, olah data dan penyelesaian kasus-kasus statistik. Yogyakarta: Mediakom.

[23] Raditya T, Daniel. Dkk. 2014. Pengaruh modal investasi minimal di BNI Sekuritas, return dan persepsi terhadap resiko pada minat investasi mahasiswa, dengan penghasilan sebagai variabel moderat. E-jurnal Ekonomi dan Bisnis Universitas Udayana ISSN: 2337-3067. Volume 3. Halaman 377-390

[24] Ratnasari, Angela Renny. 2014. Faktor-Faktor Yang Mempengaruhi Penggunaan Informasi Akuntansi Bagi Usaha Mikro Kecil Menengah (Umkm) Binaan Dinas Koperasi Dan Umkm Kota Kediri. Skripsi. Surabaya: Universitas Katolik Widya Mandala

[25] Riduwan. 2012. Belajar Mudah Penelitian Untuk Guru, Karyawan, Peneliti Pemula. Bandung: Alfabeta.

[26] Robbins, Stephen P. and Timothy. A. Judge. 2008. Perilaku Organisasi. Edisi12. Jakarta: Salemba Empat.

[27] Santoso, 2005. Metodologi Penelitian Kuantitatf dan Kualitatif. Jakarta: Prestasi Pustaka.

[28] Samir, Alfin dan Dwi Larso. 2011. Identifikasi Faktor-Faktor yang Mempengaruhi Kinerja UKM Catering di Kota Bandung. Tesis. Bandung: Institut Teknologi Bandung.

[29] Simanjuntak, Payaman J. 2005. Manajemen dan Evaluasi Kinerja. Jakarta: Lembaga Penerbit Fakultas Ekonomi UI. Diakses pada 15 Maret 2017.

[30] Solovida, Grace Tianna. 2010. Faktor-Faktor yang Mempengaruhi Penyiapan dan Penggunaan Informasi Akuntansi Pada Perusahaan Kecil dan Menengah Di Jawa Tengah. Tesis. Semarang: Fakultas Ekonomi UNDIP.

[31] Sugiyono. 2012. Statistika untuk Penelitian. Bandung: Alfabeta.

[32] Sugiyono. 2014. Metode Penelitian Manajemen Cetakan ke-2. Bandung: Alfabeta. 
[33] Supriyono, R.A. 1993. Akuntansi Manajemen I: Konsep dasar akuntansi manajemen dan proses perencanaan. Edisi 1. Yogyakarta: Penerbit BPFE

[34] Tambunan, Tulus T.H. 2009. UMKM di Indonesia. Jakarta : Ghalia Indonesia anggota IKAPI.

[35] Wahyudi, Muhamad. 2009. Analisis Faktor-faktor yang Mempengaruhi Penggunaan Informasi Akuntansi Pada Usaha Kecil dan Menengah (UKM) di Yogyakarta. Tesis. Semarang: Universitas Diponegoro.

[36] Wismiarsi, Tri, dkk. 2008. Hambatan Ekspor UKM Indonesia: Hasil Studi pada Industri Mebel, Kerajinan, dan Biofarma. Jakarta: Penerbit Kompas.

[37] Wati, Evi Emilia. 2011. Persepsi Para Pelaku Ukm (Usaha Kecil Dan Menengah) Terhadap Penerapan Akuntansi. Skripsi. Surabaya: Sekolah Tinggi Ilmu Ekonomi Perbanas.

[38] Wibowo, Alex dan Elisabeth Penti Kurniawati. 2015. Pengaruh Penggunaan Informasi Akuntansi Terhadap Keberhasilan Usaha Kecil Menengah (Studi Pada Sentra Konveksi Di Kecamatan Tingkir Kota Salatiga). Jurnal Ekonomi dan Bisnis. Volume XVIII No. 2, Agustus 2015. ISSN 1979 - 6471.

[39] Widyastuti, Tri. 2003. Topik-Topik Behaviorial Accounting: Akuntansi Manajemen Model Kontinjensi. Universitas Pancasila. Volume 2 Nomor 2

[40] ---------. Undang-Undang No 20 Tahun 2008, Undang-Undang UMKM (Usaha Mikro,Kecil,dan Menengah).

www.http://repository.wima.ac.id/4815/1/ABSTRAK.pdf. Diakses pda15 Maret 2017.

www.http://digilib.esaunggul.ac.id/public/UEU-Undergraduate-5288 LAMPIRAN.pdf. Diakses pada 15 Maret 2017.

www.http://erepo.unud.ac.id/10356/3/6463e871057f59c3533574900aef4fcb. pdf. Diakses pada 15 Maret 2017.

www.http://lp3es.or.id/index.php?option=com content\&task=view\&id=86\&Ite $\underline{\text { mid=92. }}$. Diakses pada 15 Maret 2017. 